\title{
P01.37. The use of DNA barcoding for identification of medicinal plant products: an example from plants used in the Southern Texas- Mexico border region
}

\author{
A Schwarzbach ${ }^{*}, \mathrm{H}$ Aguilar \\ From International Research Congress on Integrative Medicine and Health 2012 \\ Portland, Oregon, USA. 15-18 May 2012
}

\section{Purpose}

DNA barcoding generates a unique identification tag for individual species based on the sequence of a short stretch of DNA. For this study we evaluated the potential of DNA barcoding methods for identification of medicinal plants using examples from the Lower Rio Grande Valley border region in Texas. Many plants that enter the supply chain are not evaluated for correct identification and better and faster methods are needed for identification of fragmented samples.

\section{Methods}

We sequenced several genomic regions, both nuclear and chloroplast, in order to assess variability and ability to identify highly fragmented plant material or otherwise incomplete specimens. Unidentified samples were compared with data available in Genbank and with an extensive collection of known reference materials.

\section{Results}

We successfully used phylogenetic techniques for correct placement of the unidentified samples and potential applications for this method are discussed. We compare this method with the Genbank-BLAST search technique that is widely used for sequence matching.

\section{Conclusion}

In conclusion, DNA barcoding can be effectively used as an identification method for medicinal plant preparations that allows fast and efficient control for distributors, provides information to customers, and, in case of

University of Texas, Brownsville, Brownsville, USA a poisoning accident, might aide in determining correct treatment and countermeasures. Our studies also showed that comprehensive databases for reference materials need to be carefully assembled and curated to provide reliable information for comparisons. Currently existing databases do not fulfill this requirement leading to potential misidentifications.

Published: 12 June 2012

\section{doi:10.1186/1472-6882-12-S1-P37}

Cite this article as: Schwarzbach and Aguilar: P01.37. The use of DNA barcoding for identification of medicinal plant products: an example from plants used in the Southern Texas-Mexico border region. BMC

Complementary and

Alternative Medicine 2012 12(Suppl 1):P37.
Submit your next manuscript to BioMed Central and take full advantage of:

- Convenient online submission

- Thorough peer review

- No space constraints or color figure charges

- Immediate publication on acceptance

- Inclusion in PubMed, CAS, Scopus and Google Scholar

- Research which is freely available for redistribution
() Biomed Central

\section{() Biomed Central}

